\title{
EFEKTIVITAS PENGGUNAAN GOOGLE CLASSROOM SEBAGAI MEDIA PEMBELAJARAN DARING
}

\section{(THE EFFECTIVENESS OF USING GOOGLE CLASSROOM AS A LEARNING MEDIA)}

\author{
Munasiah $^{1}$, Lin Suciani Astuti ${ }^{2}$, Risma Nurul Auliya ${ }^{3}$ \\ ${ }^{1}$ Universitas Indraprasta PGRI, munasiahunindra@gmail.com \\ ${ }^{2}$ Universitas Indraprasta PGRI, elinsuciaja@gmail.com \\ ${ }^{3}$ Universitas Indraprasta PGRI, rismauliya@gmail.com
}

\begin{abstract}
Abstrak
Penelitian ini bertujuan untuk mengetahui efektivitas penggunaan Google Classroom sebagai media pembelajaran daring dan pembelajaran jarak jauh (PJJ). Metode penelitian yang digunakan adalah metode survey menggunakan kuisioner secara online. Penelitian ini diadakan di SDIT Ruhama dan SDI Bina Insani, Depok, Jawa barat. Jumlah sampel penelitian sebanyak 51 orang, yang terdiri dari para guru dan kepala sekolah. Sampel penelitian ditentukan dengan menggunakan metode purposive sampling. Instrumen penelitian yang digunakan dalam bentuk kuisioner, yang disebar secara online menggunakan google form. Analisis data penelitian dilakukan dengan cara menghitung nilai persentase hasil kuisioner, yang kemudian dilakukan analisis deskriptif dengan pendekatan kuantitatif. Hasil penelitian menunjukkan bahwa sebesar 83,27\% guru menggunakan Google Classroom sebagai media pembelajaran daring, 86,27\% guru menerima aplikasi ini sebagai salah satu metode pembelajaran, serta $84,41 \%$ guru merasakan kebermanfaatan dari aplikasi Google Classroom, serta 75,49\% merasakan pengaruh sosial terhadap penggunaan Google Classroom. Selain itu, pelaksanaan pembelajaran daring dengan media Google Classroom secara keseluruhan cukup efektif dengan tingkat kecenderungan sebesar $84,13 \%$. Pembelajaran daring dengan media Google Classroom dapat membantu guru dalam penyampaian materi dan pendistribusian tugas, serta sebagai tempat diskusi juga antara guru dan siswa.
\end{abstract}

Kata kunci: Google Classroom, Media Pembelajaran.

\begin{abstract}
This study aims to determine the effectiveness of using Google Classroom as an online learning media and distance learning. This research was carried out approach with survey methods using quisioner online. This research was conducted at SDIT Ruhama and SDI Bina Insani, Depok, West Java. The sample was 51 participants, consisting of teachers and principals which is determined by purposive sampling. Data was collected by online questionnaire using google form. The data analyzed by calculating the percentage of the questionnaire results and descriptive analysis with a quantitative approach. The results showed that $83.27 \%$ of teachers using Google Classrooms as an online learning media, $86.27 \%$ of teachers accepted this application as a learning method, $84.41 \%$ of them get the benefits of this application, and $75.49 \%$ of them felt social influence on using Google Classroom. In addition, the implementation of online learning with Google Classroom media is quite effective as a whole with a tendency of 84.13\%. This learning method could assist teachers in delivering the learning materials
\end{abstract}


and distributing assignments, as well as gives teacher and students more ways to communicate.

Keywords: Google Classroom, Learning Media.

\section{PENDAHULUAN}

Pada Maret 2020, Indonesia dilanda bencana wabah virus corona (Covid19). Corona virus adalah kumpulan virus yang bisa menginfeksi sistem pernapasan. Pada Sebagian besar kasus yang terjadi, virus ini hanya mengakibatkan infeksi pernapasan ringan, seperti flu. Namun, Pane (2020) menyatakan bahwa virus ini juga bisa mengakibatkan infeksi pernapasan berat, seperti infeksi paru-paru (pneumonia). Penyebaran virus Covid-19 yang sangat cepat ke seluruh dunia menimbulkan perubahan pola aktivitas pada seluruh sektor kehidupan manusia. Salah satu cara untuk mengatasi penyebaran Covid-19 ini, yaitu dengan melakukan pembatasan social (social distancing) dan pembatasan fisik (physical distancing). Tak terkecuali Indonesia yang menerapkan kebijakan Pembatasan Sosial Berskala Besar (PSBB) untuk mengurangi penyebaran virus ini (Pane, 2020).

Penyebaran virus yang sangat cepat tersebut membuat pemerintah mengambil kebijakan di segala bidang termasuk bidang pendidikan. Pemerintah Indonesia memutuskan untuk meniadakan seluruh aktivitas pendidikan secara tatap muka. Berdasarkan arahan dari Kementerian Pendidikan dan Kebudayaan (Kemendikbud), Indonesia memberlakukan kebijakan belajar di rumah dengan sistem pembelajaran jarak jauh melalui metode pembelajaran daring (online). Pembelajaran daring ini diberlakukan bagi setiap kalangan pelajar dan mahasiswa di seluruh wilayah Indonesia dan bertujuan untuk memutus mata rantai penyebaran Covid-19 (Purandina \& Winaya, 2020).

Pembelajaran daring bertujuan untuk memenuhi standar pendidikan dengan pemanfaatan teknologi informasi, seperti media komputer atau gawai. Dengan pembelajaran daring ini, guru masih tetap berkomunikasi dengan siswa tanpa harus bertatap muka secara langsung, tanpa ada batasan ruang dan waktu. Pembelajaran daring dilakukan melalui berbagai media yang dapat menunjang proses pembelajaran, salah satunya yaitu Google Classroom.

Google Classroom adalah suatu teknologi berbasis web yang digunakan dalam bidang pendidikan untuk memfasilitasi proses belajar-mengajar (Gupta \& Pathania, 2021). Saat ini, Google Classroom menjadi salah satu platform pembelajaran yang populer, karena dapat menampung lebih dari 30 juta tugas yang diunggah oleh guru dan siswa (Salam, 2020). Dengan demikian, Google Classroom dapat digunakan sebagai wadah untuk memberikan dan mengunggah tugas bahkan menilai tugas yang telah dikumpulkan (Nirfayanti \& Nurbaeti, 2019). Selain itu, Google Classroom juga mempunyai kemampuan untuk membuat salinan otomatis dari tugas yang sudah dikerjakan, dalam aplikasi ini tidak terdapat iklan dan bersifat gratis (Utami, 2019). Lebih lanjut, Abidin \& Saputro (2020) menambahkan bahwa dengan Google Classroom, guru dapt memberikan tugas secara online, meningkatkan kerjasama baik antarguru, guru dan siswa, maupun antarsiswa, serta mengembangkan komunikasi yang baik dengan siswa setiap saat. Oleh karena itu, dapat disimpulkan bahwa aplikasi Google Classroom dapat dimanfaatkan untuk membantu guru dan siswa 
berinteraksi dalam pelaksanaan pembelajaran daring.

Berdasarkan latar belakang yang telah dipaparkan sebelumnya, penelitian ini dilakukan untuk mengetahui efektivitas penggunaan Google Classroom sebagai media pembelajaran daring. Penelitian ini diharapkan dapat memberikan informasi dan masukan bagi kepala sekolah maupun guru dalam usaha melakukan pembelajaran daring yang lebih baik di masa pandemi.

\section{KAJIAN TEORI}

\section{Pembelajaran Daring}

Pembelajaran daring (online) saat ini dilaksanakan sebagai salah satu cara untuk memutus mata rantai Covid-19. Pembelajaran daring merupakan pembelajaran yang dapat memfasilitasi pembelajaran yang dapat dilakukan kapan saja dan di mana saja, tanpa terbatas oleh jarak dan waktu, serta tanpa harus bertatap muka (Utami, 2019). Pembelajaran daring dilakukan melalui media berupa internet dan alat penunjang berupa komputer atau gawai. Lebih lanjut, pembelajaran daring menekankan siswa agar lebih teliti dan jeli dalam menerima dan mengolah informasi yang disajikan secara daring (Putria, Maulana \& Uswatun, 2020). Hal ini sejalan dengan hasil penelitian yang dilakukan oleh Sadikin \& Hamidah (2020) yang menyatakan bahwa pembelajaran daring yang lebih berpusat pada siswa mampu menumbuhkan kemandirian belajar serta tanggung jawab dalam belajar.

Akan tetapi, pembelajaran jarak jauh dengan sistem daring ini juga menimbulkan polemik bagi sekolah, guru, siswa, maupun orang tua. Sekolah kesulitan untuk menyediakan akses jaringan internet yang baik bagi guru yang tetap diharuskan untuk datang ke sekolah. Selain itu, guru merasa belum siap dan kesulitan dalam menggunakan aplikasi dan mengelola proses pembelajaran, serta menentukan standar penilaian yang objektif (Ariadhy et al., 2020). Selain itu, siswa belum dapat beradaptasi dengan pembelajaran jarak jauh karena terbiasa belajar tatap muka, ditambah dengan tidak tersedianya sarana dan prasarana yang memadai di rumah.

Lebih jauh, pelaksanaan pembelajaran daring juga menambah beban pengeluaran orang tua untuk pembelian paket data internet. Selain itu, orang tua juga dipaksa untuk mempelajari cara penggunaan media dalam pembelajaran daring (Purwanto et al., 2020), sehingga mereka dapat menemani anak-anaknya selama proses pembelajaran, mulai dari persiapan, pelaksanaan, hingga evaluasi. Orang tua harus selalu memberikan semangat kepada anaknya selama proses pembelajaran, karena keterlibatan orang tua dinilai memiliki peranan penting dalam prestasi belajar anak.

\section{Google Classroom}

Google Classroom adalah layanan web gratis dari Google untul sekolah, yang bertujuan untuk menyederhanakan pembuatan, pendistribusian, dan penilaian tugas, tanpa menggunakan kertas. Tujuan utama dari Google Classroom adalah untuk mengefisiensikan proses penyebaran dokumen antara guru dan siswa. Google Classroom pertama kali diperkenalkan sebagai suatu fitur G-Suite 
bagi pendidikan, yang kemudian dirilis secara resmi pada 12 Agustus 2014. Pada tahun 2014 sampai dengan 2016, pengembangan Google Classroom tidak diperuntukkan bagi semua orang, tetapi hanya bagi sekolah yang bekerjasama dengan Google. Namun, pada Maret 2017, Google Classroom dapat diakses oleh seluruh orang dengan menggunakan Google pribadi (Wicaksono \& Rachmadyanti, 2016). Selain itu, Google Classroom dapat diakses secara gratis melalui komputer maupun gawai. Aplikasi ini dapat diunduh melalui playstore pada Android atau app store pada iOS.

Google Classroom merupakan sebuah aplikasi berbasis internet yang memungkinkan terciptanya ruang kelas di dunia maya. Google Classroom adalah platform yang berorientasi pada pembelajaran sekolah secara hybrid, serta dirancang untuk menyederhanakan dalam proses pemberian dan pengerjaan tugas tanpa menggunakan kertas. Selain itu, Google Classroom dapat dengan mudah untuk disinkronkan dengan layanan Google lainnya seperti google drive, sehingga dapat menyederhanakan penyimpanan dan pengaturan data $(\mathrm{Ni}, 2020)$. Dengan menggunakan aplikasi ini, guru hanya perlu untuk membuat kelas dan membagikan kode kelas tersebut kepada siswa, sehingga siswa dapat bergabung dalam kelas tersebut (Oktaria \& Rahmayadevi, 2021).

Kelebihan utama dari Google Classroom, yaitu penghematan waktu dan fitur yang sangat sederhana, sehingga mudah untuk digunakan (Suharsana et al., 2019). Izenstark \& Leahy (2015) mengemukakan beberapa kelebihan dari Google Classroom sebagai salah satu bagian dari Learning Management System (LMS), antara lain:

1. Memiliki proses pengaturan yang cepat dan nyaman

Proses pengaturan Google Classroom sangat cepat dan nyaman daripada melakukan pemasangan atau pendaftaran pada LMS lokal atau provider. Guru dengan pengalaman penggunaan e-learning yang beragam tetap dapat mengaksesnya dengan mudah dan melakukan pendistribusian materi pelajaran dan tugas pada siswa.

2. Menghemat waktu

Siswa tidak perlu untuk mengunduh tugas tertentu dari guru. Guru hanya perlu membuat dan mendistribusikan bahan ajar pada siswa secara online. Selain itu, guru dapat menilai dan memberikan umpan balik untuk semua tugas siswa, bahkan dapat menentukan peringkat setiap siswa. Seluruh proses yang dilakukan tanpa kertas, sehingga tidak ada waktu yang terbuang untuk mendistribusikan dokumen fisik. Metode pembelajaran ini juga dapat disesuaikan dengan jadwal harian siswa, sehingga siswa dapat menyelesaikan tugas secara online sesuai dengan tenggat waktu yang diberikan oleh guru.

3. Meningkatkan kerjasama dan komunikasi

Salah satu manfaat penting dari penggunaan Google Classroom, yakni mewujudkan suatu kolaborasi secara daring yang efisien. Guru dapat mengirimkan pemberitahuan kepada siswanya untuk memulai diskusi atau aktivitas pembelajaran secara daring. Selain itu, siswa memiliki kesempatan untuk memberikan umpan balik pada temannya dengan menuliskannya pada alur diskusi di Google Classroom. Kemudian, jika mereka membutuhkan 
bantuan karena mengalami kesulitan dalam memahami tugas atau ingin mempelajari topik-topik tertentu, mereka akan mendapatkan respon secara langsung dari teman virtual mereka.

4. Penyimpanan data yang terpusat

Dengan Google Classroom, semua partisipan termasuk guru dan siswa memiliki akses secara terpusat. Siswa dapat melihat seluruh tugas pada suatu folder khusus, dan mengetahui nilai pada aplikasi ini. Selain itu, guru dapat menyimpan materi dan aktivitas pembelajaran pada penyimpanan cloud. Mereka tidak perlu khawatir jika dokumen-dokumen tersebut akan hilang, karena semuanya tersimpan pada LMS gratis ini.

5. Pembagian bahan ajar yang cepat

Guru/ fasilitator pembelajaran daring memiliki akses untuk membagikan informasi dan bahan ajar, sehingga tidak perlu mengirim email satu per satu kepada masing-masing siswa. Guru hanya membagikan tautan mengenai materi yang akan diberikan pada siswanya.

\section{METODE}

Penelitian ini merupakan penelitian menggunakan metode survei. Penelitian ini dilakukan di SDIT Ruhama dan SDI Bina Insani, Depok, Jawa Barat. Sampel penelitian yang digunakan berjumlah 51 orang, yang ditentukan dengan metode purposive sampling.

Data yang diperoleh berupa data kuisioner yang diisi oleh para guru yang menggunakan Google Classroom sebagai media pembelajaran daring, yang meliputi penerapan Google Classroom, penerimaan terhadap Google Classroom, kegunaan Google Classroom, pengaruh sosial terhadap penggunaan Google Classroom. Teknik pengumpulan data yang digunakan dalam penelitian ini adalah menggunkan kuisioner daring dengan google form. Selanjutnya, analisis data dilakukan dengan menghitung nilai persentase hasil kuisioner dan analisis deskriptif dengan pendekatan kuantitatif. Analisis deskripsi data dalam penelitian ini dimaksudkan untuk mendeskripsikan dan memaknai keefektifan Google Classroom sebagai media pembelajaran daring. Untuk mendeskripsikan digunakan kriteria pada tabel 1 .

Tabel 1. Kriteria penilaian keefektifan untuk analisis deskriptif

\begin{tabular}{lcc}
\hline No & Rumus & Klasifikasi \\
\hline 1. & $M_{\mathrm{i}}+1,5 S D_{\mathrm{i}} \leq M \leq M_{\mathrm{i}}+3 S D_{\mathrm{i}}$ & Efektif \\
2. & $M_{\mathrm{i}}+0 S D_{\mathrm{i}} \leq M<M_{\mathrm{i}}+1,5 S D_{\mathrm{i}}$ & Cukup efektif \\
3. & $M_{\mathrm{i}}-1,5 S D_{\mathrm{i}} \leq M \leq M_{\mathrm{i}}+0 S D_{\mathrm{i}}$ & Tidak efektif \\
4. & $M_{\mathrm{i}}-3 S D_{\mathrm{i}} \leq M \leq M_{\mathrm{i}}-1_{2} 5 S D_{\mathrm{i}}$ & Sangat tidak efektif \\
\hline
\end{tabular}

Keterangan:

$M_{i}=$ rerata ideal $=1 / 2($ skor maksimum ideal + skor minimum ideal $)$

$S D_{i}=$ standar deviasi $=1 / 6$ (skor maksimum ideal - skor minimum ideal)

$M$ = skor empiris 


\section{HASIL DAN PEMBAHASAN}

Berdasarkan hasil analisis data, presentase indikator keefektifan penggunaan Google Classroom dapat dilihat pada tabel berikut.

Tabel 2. Kriteria penilaian Indikator Efektivitas Penggunaan Google Classroom.

\begin{tabular}{llc}
\hline No & \multicolumn{1}{c}{ Indikator } & Presentase \\
\hline 1. & Penggunaan Google Classroom & $83,27 \%$ \\
2. & Penerimaan terhadap aplikasi Google Classroom & $86,27 \%$ \\
3. & Kegunaan Google Classroom & $84,41 \%$ \\
4. & Pengaruh sosial terhadap penggunaan Google Classroom & $75,49 \%$ \\
\hline
\end{tabular}

Adapun diagram batang yang menyatakan hasil persentase Google Classroom sebagai media pembelajaran daring adalah sebagai berikut.

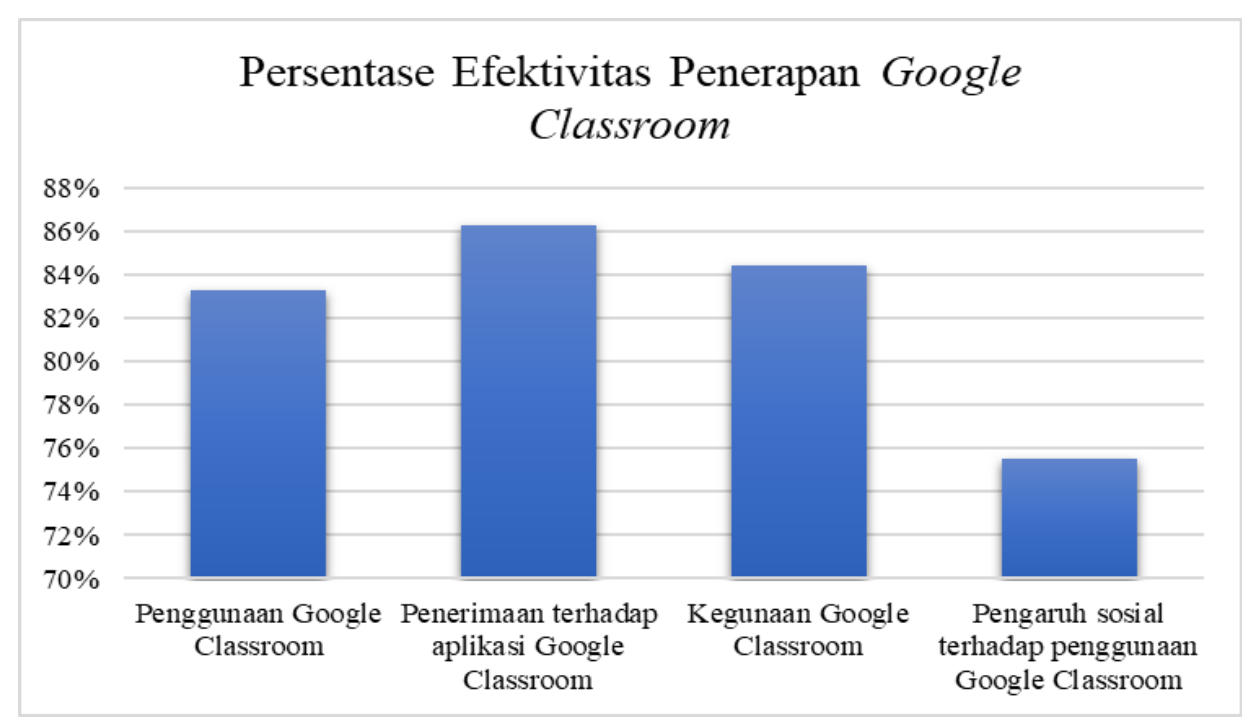

Gambar 1. Persentase Efektivitas Penerapan Google Classroom sebagai Media Pembelajaran Daring

Tabel 2 menunjukkan bahwa persentase tertinggi adalah indikator penerimaan terhadap aplikasi Google Classroom, yaitu sebanyak 86,27\% siswa menerima aplikasi ini sebagai salah satu metode pembelajaran yang digunakan guru untuk menyampaikan materi pelajaran. Hal ini didukung oleh pendapat yang dikemukakan oleh Abidin \& Saputro (2020), yaitu pemanfaatan teknologi dalam pembelajaran, seperti Google Classroom, dapat meningkatkan penerimaan siswa terhadap materi pelajaran. Selain itu, siswa berpendapat bahwa penggunaan Google Classroom relatif sederhana karena memberikan beberapa pilihan aksesbilitas (Oktaria \& Rahmayadevi, 2021). Jika siswa gagal dalam memasang aplikasi pada gawai, mereka tetap dapat mengaksesnya melalui email atau web browser. Selain itu, walaupun siswa tidak dapat mengikuti pembelajaran secara langsung karena terkendala sinyal internet, mereka tetap memiliki kesempatan untuk mengakses materi pelajaran yang diberikan di lain waktu.

Lebih lanjut, indikator pengaruh sosial terhadap penggunaan Google Classroom memiliki persentase terendah, yaitu $75,49 \%$. Keterbatasan sinyal dan 
kuota internet dan ekonomi merupakan salah satu faktor utama yang dapat menghambat pembelajaran online. Hal ini sejalan dengan pernyataan yang dikemukakan oleh Alim et al. (2019), yakni penggunaan Google Classroom dalam pembelajaran di sekolah perlu didukung oleh fasilitas teknologi yang memadai, seperti perangkat komputer/ smartphone, sinyal dan kuota internet. Faktor lainnya yaitu keterbatasan kemampuan orang tua siswa dalam memahami penggunaan aplikasi Google Classroom dalam proses pembelajaran, sedangkan peran orang tua dianggap sangat penting untuk memantau aktivitas belajar siswa. Oleh karena itu, guru perlu untuk selalu memantau siswa satu per satu dan memastikan mereka memahami materi pelajaran yang sedang didiskusikan (Abidin \& Saputro, 2020).

Hasil penelitian juga menunjukkan bahwa lebih dari $80 \%$ guru yang menggunakan aplikasi Google Classroom berpendapat bahwa aplikasi ini bermanfaat sebagai media penyampaian materi dalam pembelajaran daring. Melalui Google Classroom, guru dapat mengunggah materi kemudian siswa dapat mempelajarinya dan melakukan diskusi jika ada hal yang kurang dipahami. Dari materi tersebut siswa juga dapat menerapkan pengetahuannya untuk menyelesaikan tugas yang diberikan oleh guru, dengan pembelajaran daring ini melatih siswa untuk berpikir kritis. Hal ini sejalan dengan hasil penelitian yang dilakukan oleh Abidin \& Saputro (2020) dan Ulam (2020), yang menyatakan bahwa Google Classroom merupakan media yang efektif untuk digunakan dalam pembelajaran dikarenakan guru dapat merancang kelas virtual, mendistribusikan tugas, dan memantau seluruh aktivitas siswa hanya dengan menggunakan satu media saja, yaitu Google Classroom.

Tabel 3. Distribusi Kecenderungan Keefektifan Penggunaan Google Classroom sebagai Media Pembelajaran Daring

\begin{tabular}{clccc}
\hline No & \multicolumn{1}{c}{ Rumus } & Frekuensi & Presentase & Klasifikasi \\
\hline 1. & $80 \leq M \leq 100$ & 0 & 0 & Efektif \\
2. & $60 \leq M<80$ & 43 & $84,31 \%$ & Cukup efektif \\
3. & $40 \leq M \leq 60$ & 7 & $13,73 \%$ & Tidak efektif \\
4. & $20 \leq M \leq 40$ & 1 & $1,96 \%$ & Sangat tidak efektif \\
& Total & 51 & $100 \%$ & \\
\hline
\end{tabular}

Tabel 3 menunjukkan bahwa pelaksanaan pembelajaran daring dengan media Google Classroom secara keseluruhan cukup efektif dengan tingkat kecenderungan sebesar $84,13 \%$. Hal ini senada dengan penelitian yang dilakukan oleh Suhada et al. (2020) yang menyatakan bahwa 60,42\% mahasiswa berpendapat penggunaan aplikasi Google Classroom efektif untuk pembelajaran daring. Keefektifan pembelajaran daring dengan menggunakan Google Classroom juga terlihat dari antusiasme siswa saat mengikuti diskusi dan ketepatan waktu dalam pengumpulan tugas. Siswa berpandangan bahwa pembelajaran dengan Google Classroom lebih menarik, hidup, dan menyenangkan, serta suasana pembelajaran di kelas pun lebih santai (Gupta \& Pathania, 2021). Selain itu, siswa juga memiliki lebih banyak waktu untuk memahami materi dan tidak perlu susah payah untuk mencatat materi tersebut.

Di sisi lain, melalui pembelajaran Google Classroom, guru dapat berinteraksi dengan siswa tanpa ada batas ruang waktu. Hal ini juga sejalan 
dengan pernyataan yang dikemukakan oleh Sudarsana et al. (2019) dalam penelitiannya, yaitu penggunaan Google Classroom dalam pelaksanaan pendidikan di Indonesia dinilai ramah lingkungan dan dapat menghemat waktu, serta dapat meningkatkan kualitas kerjasama dan komunikasi guru dan siswa. Guru dapat langsung berinteraksi dengan siswanya baik secara individua tau kelompok ketika mereka mengalami kesulitan (Alim et al. 2019). Dengan demikian, guru mampu untuk memantau perkembangan kompetensi pada setiap siswa (Alim et al. 2019).

\section{SIMPULAN DAN SARAN}

Pembelajaran daring dengan menggunakan media Google Classroom pada sekolah dasar, khususnya di Depok dinilai efektif karena membantu guru dalam penyampaian materi dan pendistribusian tugas, serta sebagai tempat diskusi juga antara guru dan siswa. Pernyataan tersebut didukung dari hasil survei yang menunjukkan angka sebesar $84,31 \%$ guru menyatakan Google Classroom efektif digunakan sebagai media pembelajaran daring. Akan tetapi, perlu diperhatikan bahwa dalam penggunaan Google Classroom, guru memiliki peranan penting dalam pembelajaran, terutama dalam proses diskusi. Guru berperan sebagai mediator agar diskusi berjalan dengan baik, seluruh siswa tetap fokus dan aktif selama pembelajaran berlangsung.

\section{DAFTAR RUJUKAN}

Abidin, Z. \& Saputro, T. M. E. (2020). Google classroom as a mathematics learning space: potentials and challenges. Journal of Physics: Conference Series, 1567, 1-6. (Online), (doi:10.1088/1742-6596/1567/2/022094).

Alim, N., Linda, W., Gunawan, F. \& Saad, M. S. M. (2019). The effectiveness of google classroom as an instructional media: a case of state Islamic institute of Kendari, Indonesia. Humanities \& Social Sciences Reviews, 7(2), 240-246. (Online), (https://doi.org/10.18510/hssr.2019.7227).

Ariadhy, S. Y., Nurohman, S., Arkum, D., Handini, W. \& Ferdiana, F. (2020). Pelatihan pembelajaran jarak jauh di era pandemi covid-19. Jurnal Anoa, 1(3), 220-226. (Online), (http://dx.doi.org/10.52423/anoa.v1i3.13640).

Gupta, A. \& Pathania, P. (2021). To study the impact of google classroom as a platform of learning and collaboration at the teacher education level. Education and Information Technologies, 26, 843-857. (Online), (https://doi.org/10.1007/s10639-020-10294-1).

Izenstark, A., \& Leahy, K. L. (2015). Google classroom for librarians: features and opportunities. Library Hi Tech News, 32(9), 1-3. (Online), (http://dx.doi.org/10.1108/LHTN-05-2015-0039).

$\mathrm{Ni}$, L. B. (2020). Blended learning through google classroom. International Journal of Educational and Pedagogical Sciences, 14(4), 215-221. (Online), (doi.org/10.6084/m9.figshare.12489845).

Nirfayanti, N. \& Nurbaeti, N. (2019). Pengaruh media pembelajaran google 
classroom dalam pembelajaran analisis real. Jurnal Penelitian Matematika dan Pendidikan Matematika, 2, 50-59. (Online), (https://journal.uncp.ac.id/index.php/proximal/article/view/1176).

Oktaria, A. A. \& Rahmayadevi, L. (2021). Students' perceptions of using google classroom during the covid-19 pandemic. International Journal of Educational Management and Innovation, 2(2), 153-163. (Online), (doi: 10.12928/ijemi.v2i2.3439).

Pane, M. C. (2020). Virus Corona. (Online), (https://www.alodokter.com/VirusCorona).

Purandina, I. P. Y. \& Winaya, I. M. A. (2020). Pendidikan karakter di lingkungan keluarga selama pembelajaran jarak jauh pada masa pandemi covid-19. Cetta: Jurnal Ilmu Pendidikan, 3(2), 270-290. (Online), (https://doi.org/10.37329/cetta.v3i2.454).

Purwanto, A., Pramono, R., Asbari, M., Hyun, C. C., Wijayanti, L. M., Putri R. S. \& Santoso, P. B (2020). Studi eksploratif dampak pandemi covid-19 terhadap proses pembelajaran online di sekolah dasar. Journal Education, Psychology and Counseling, 2(1), 1-12. (Online), (https://ummaspul.ejournal.id/Edupsycouns/article/view/397).

Putria, H., Maulana, L. H. \& Uswatun, D. A. (2020). Analisis proses pembelajaran dalam jaringan (daring) masa pandemi covid-19 pada guru sekolah dasar. Jurnal Basicedu, 4(2), 861-872. (Online), (https://doi.org/10.31004/basicedu.v4i4.460).

Sadikin, A., \& Hamidah, A. (2020). Pembelajaran daring di tengah wabah covid19. Jurnal Ilmiah Pendidikan Biologi Biodik, 6(2), 109-119. (Online), (https://doi.org/10.22437/bio.v6i2.9759).

Salam, U. (2020). The students' use of google classroom in learning english. Jurnal Pendidikan Indonesia (JPI), 9(4), 628-638. (Online), (doi: 10.23887/jpi-undiksha.v9i4.27163).

Sudarsana, I. K., Putra, I. B. M. A., Astawa, I. N. T. \& Yogantara, I. W. L. (2019). The use of google classroom in the learning process. IOP Conf. Series: Journal of Physics: Conf. Series, 1175, 1-5. (Online), (doi:10.1088/17426596/1175/1/012165).

Suhada, I., Kurniati, T., Pramadi, A. \& Listiawati, M., Biologi, P. P., Gunung, S., \& Bandung, D. (2020). Pembelajaran Daring Berbasis Google Classroom Mahasiswa Pendidikan Biologi pada Masa Wabah Covid-19. (Online),(http://digilib.uinsgd.ac.id/30584/1/Artikel\%20Fix\%20\%28p\%2 0idad\%20dkk\%29-dikonversi.pdf).

Utami, R. (2019). Analisis respon mahasiswa terhadap penggunaan google classroom pada mata kuliah psikologi pembelajaran matematika. Prisma, Prosiding Seminar Nasional Matematika, 2, 498-502. (Online), (https://journal.unnes.ac.id/sju/index.php/prisma/article/view/29040/1277 9).

Wicaksono, V. D. \& Rachmadyanti, P. (2016). Pembelajaran blended learning 
melalui google classroom di sekolah dasar. Seminar Nasional Pendidikan Pgsd UMS \& Hdpgsdi Wilayah Jawa, 513-521. (Online), (https://publikasiilmiah.ums.ac.id/bitstream/handle/11617/9144/44.pdf?se quence $=1 \#: \sim:$ text=Blended $\% 20$ learning $\% 20$ merupakan $\% 20$ pembelajaran $\%$ 20yang,kelas\%20dan\%20di\%20luar\%20kelas.\&text=Google\%20classr oom\%20merupakan\%20aplikasi\%20pembelajaran,dan\%20siswa\%20di\% 20sekolah\%20dasar.). 